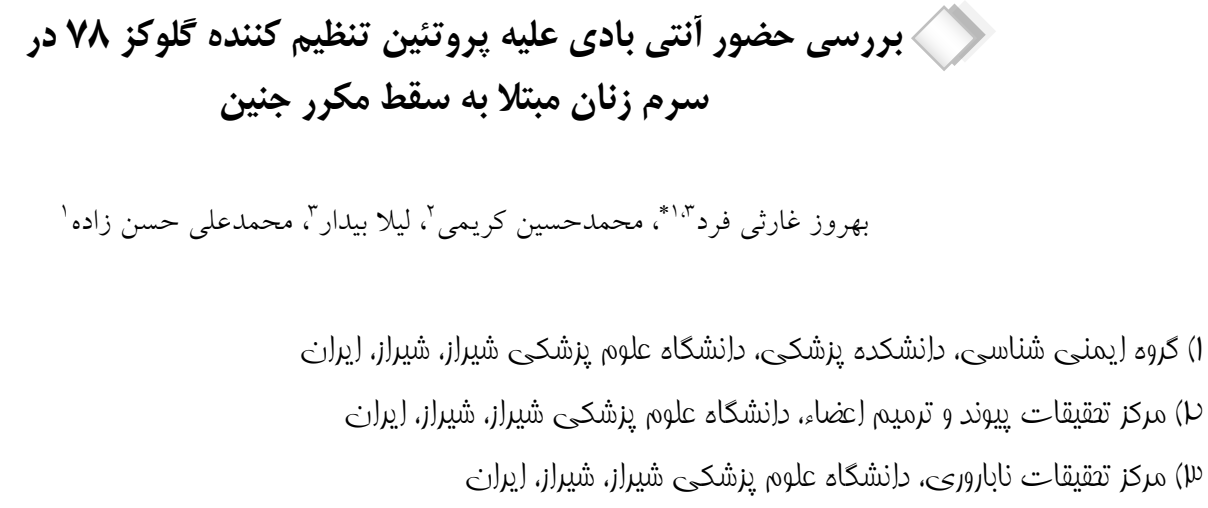

تاريخ پيذيرش:

تاريخ دريافت:

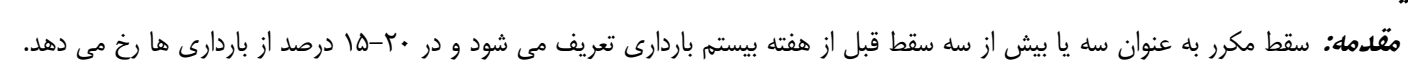

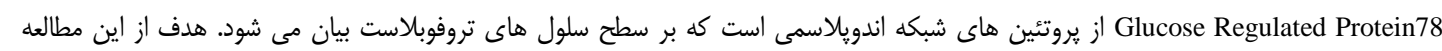
بررسى حضور آنتى بادى ضد GRP78 در زنان مبتلا به سقط هاى مائ مكرر است.

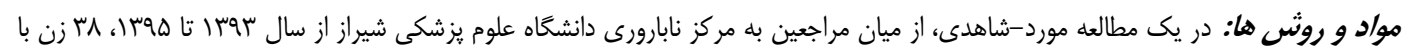

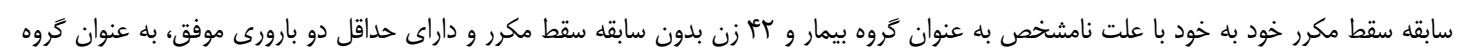

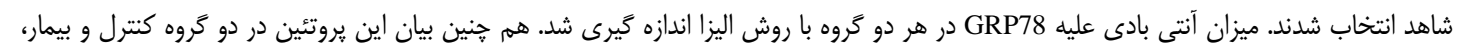

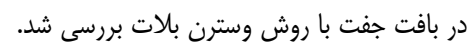

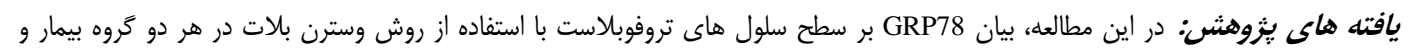

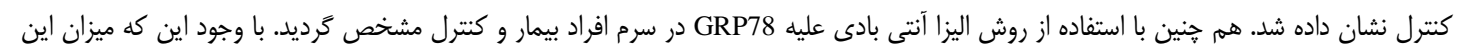

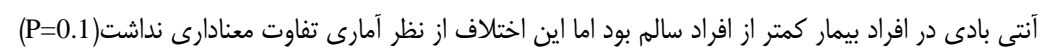

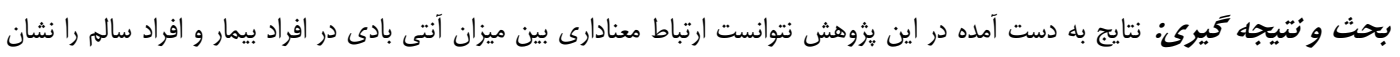

وازه هاى كليدى: حاملگیى، يلاسنتا، سقط مكرر، GRP78

* نويسنده مسئول: گروه ايمنى شناسى، دانشكده يزشكى، دانشخاه علوم يزشكى شيراز، شيراز، ايران-مركز تحقيقات نابارورى، دانشخاه علوم بزشكى شيراز، شيراز، ايران

Email: gharesifb@sums.ac.ir

Copyright () 2018 Journal of Ilam University of Medical Science. This is an open-access article distributed under the terms of the Creative Commons Attribution international 4.0 International License (https://creativecommons.org/licenses/by-nc/4.0/) which permits copy and redistribute the material, in any medium or format, provided the original work is properly cited. 
خانواده يروتئين هاى شوى حرارتى •V كيلو دالتونى استG(9). GPR78 بر روى سلول هاى سرطانى و ساير

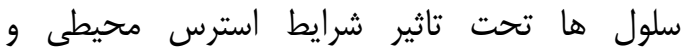
هييوكسى القاء مى شود و اين مولكول با اختلال در عملكرد و هموستاز شبكه اندويلاسميك مانع از ايويتوز

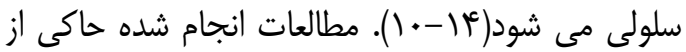
نقش GPR78 در تهاجم سلول هاى تروفوبلاست

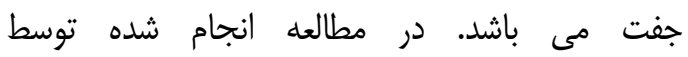
Gonzalez Gronow كه آنتى بادى عليه اين يروتئين در سرطان يروستات

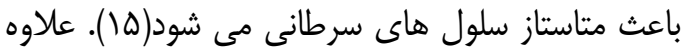
بر سرطان يروستات، نقش اين يروتئين و آنتى بادى لنائ عليه آن در سرطان هاى معده و تخمدان و هياتوسلولار كارسينوما و ميزان متاستاز آن ها نيز نشان داده شده است(T)|. در برخى از مشكلات باردارى نظير بيمارى

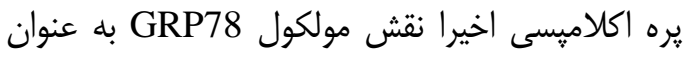

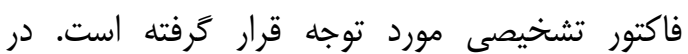

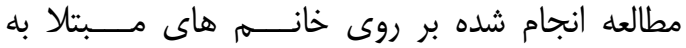

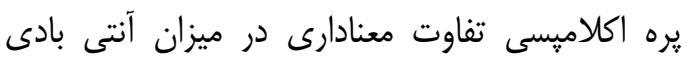
عليه اين يروتئين در سرم افراد مبتلا به نوع شديد إنايد بيمارى نسبت به افراد كنترل مشاهده شده است(و). از جمله مكانيسم هايى كه مى تواند سقط مكرر جنين رال

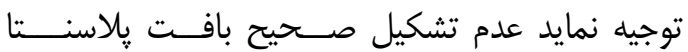
مى باشد. در تاييد اين مطلب عدم شكل گيرى صحيح بافت جفت در اختلالات باردارى نظير يره اكلاميسى و وائل سقط جنين گزارش شده است(ع) إ). يروتئين GRP78

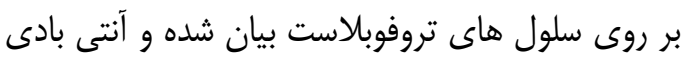

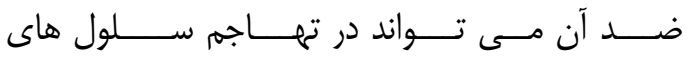

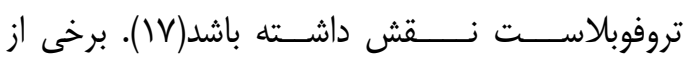

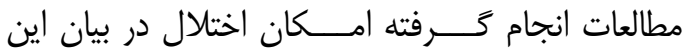

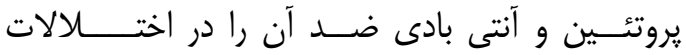

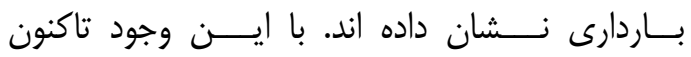

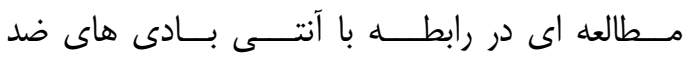

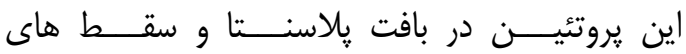

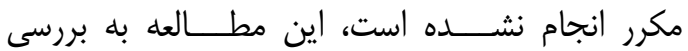

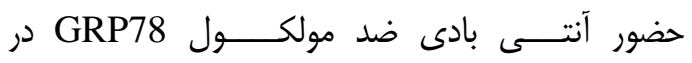

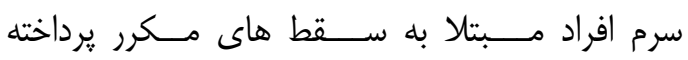

\section{مقدمه - - مق}

سقط مكرر خود به خودى بله معناى از دست دادن محصولات حاملگى و به عنوان يك رويداد تكراريذير از

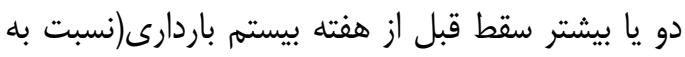

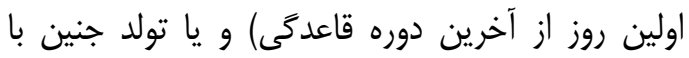

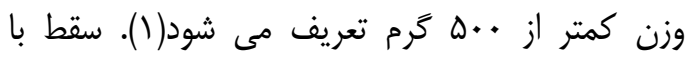

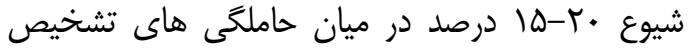

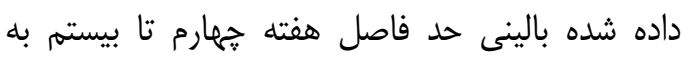

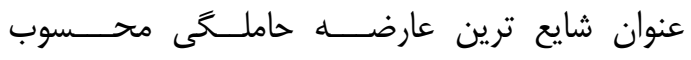
مى شود(Y). سقط مكرر جنين به دو گروه اوليه و ثانويه تقسيم مى شود. به طورى كه در سقط هاى مكرر اوليه،

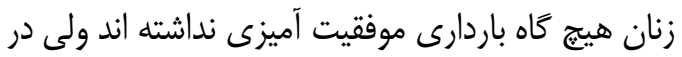

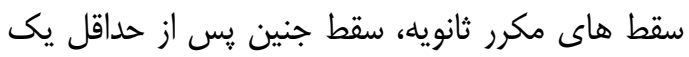

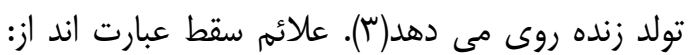
تهوع، تورم سينه، خونريزى و يا لكه بينى كه هر لحظه شديدتر مى شود، خروج لخته هاى بزرى و غليظ خون

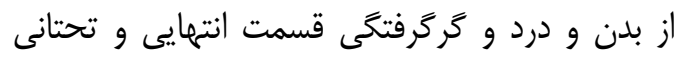

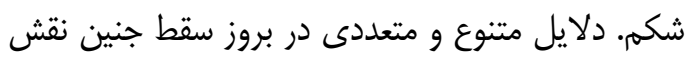
دارند كه عبارتند از حالات غيرطبيعى شكل رحم،

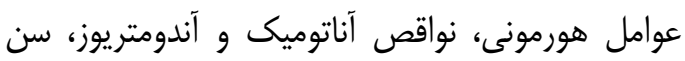

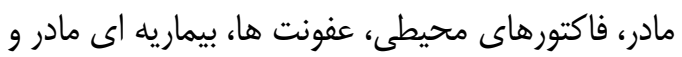
اختلالات كروموزومى و زنتيكى. بيشترين علت سقط

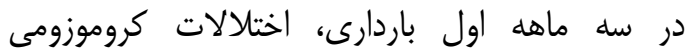
است(أ). علاوه بر علل ذكر شده، سيستم ايمنى نقش

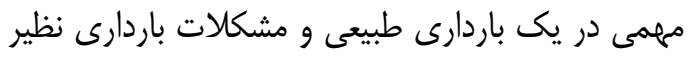

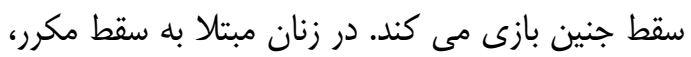
سيستم ايمنى هومورال عليه اجزاى سلولى و بافتى، اتو آنتى بادى هاى مختلفى را توليد مى كند(ه). مطالعات آنسات

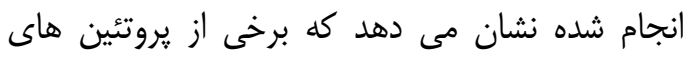
بافت يلاسنتا نيز ممكن است هدف واكنش سيستم ايمنى از طريق توليد اتو آنتى بادى ضد پيلاسنتا قرار كيرند. از جمله يروتئين هاى كه به نظر مي رسد هدف آنس

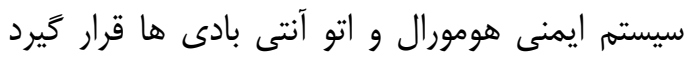
GRP78 VA براى اولين بار به عنوان يك يروتئين GPR78 كيلودالتونى كه سنتز آن در كشت سلولى محروم از

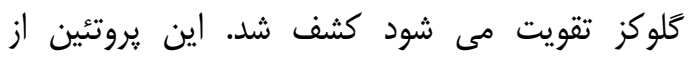
شناخته شده ترين خايرون هاى شبكه اندويلاسمى و از 
غلظت يروتئين هاى استخراج شده حدود دو ميكروگرم به ازاى هر ميكروليتر به دست امد.

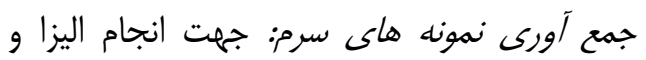

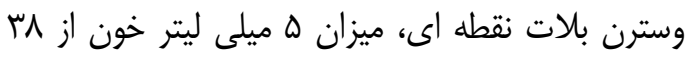

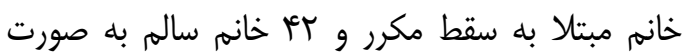
غير ناشتا و در زمان صبح به صورت داوطلبانه و ويس از اخذ رضايت نامه آكاهانها(تاييد شده توسط كميته اخلاق دانشكاه علوم يزشكى شيراز) جمع آورى كَرديد. نمونه تانه سرم از خون هاى جمع آورى شده با انجام سانتريفيوز

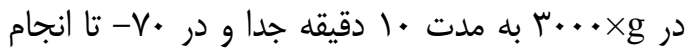

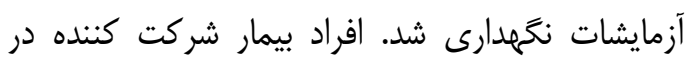

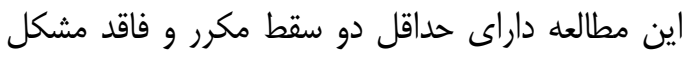
زنتيكى، هورمونى، آناتوميكى، عفونت هاى داى ويروسى و و مشكلات تيروئيدى بودند و افراد سالم فاقد سابقه سقط و بيمارى هاى خودايمنى و داراى حداقل r ب باردارى موفق قبلى بودند. الكتروفورز دو بعدى: با استفاده از اين تكنيك ابتدا يروتئين ها در بعد اول بر اساس PH ايزوالكتريك جدا

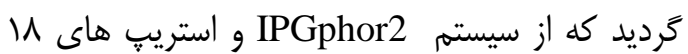
سانتى مترى خطى با PH:5-8 و PH:4-7 جهت ايزوالكتروفوكوسينگ استفاده شد. در مرحله بعد و و در

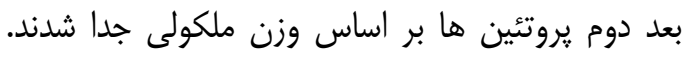
كه بعد از متعادل سازى بر روى استريِ ها، الكتروفورز

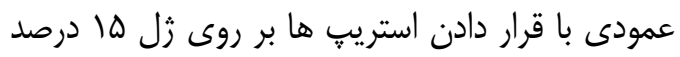
SDS-PAGE

وسترن بلات: جهت بررسى و تايسـيد حضـــور

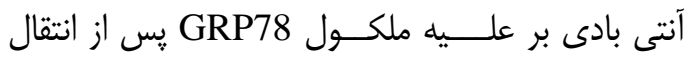

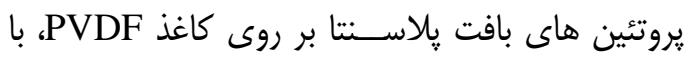

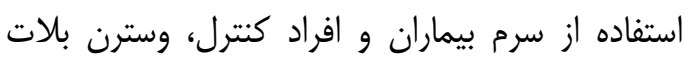

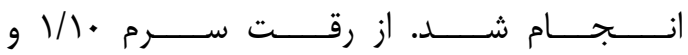
تكنيك)DAB(diaminobenzidine و نمونه هاى مخلوط شده سرم جهت وسترن بلات استفاده شد.

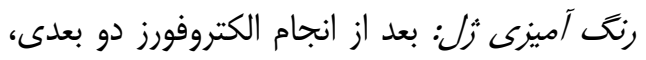

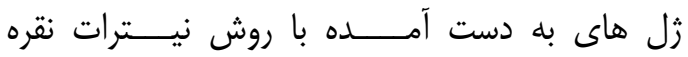
رنخ آميزى شدند.

اليزا: به علت نبود كيت الايزا به صورت تجاندى

براى سنجش ميزان آنتى بادى عليه يروتئين GRP78

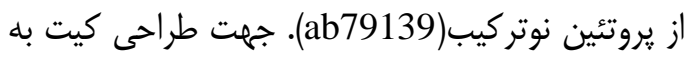

\section{مواد و روش ها}

در يك مطالعه مورد-شاهدى، ش خانم مبتلا به سقط مكرر با علت نامشخص، به عنوان گروه بيماران و

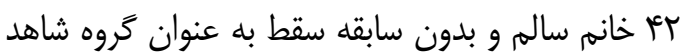

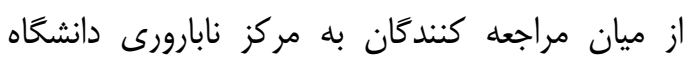

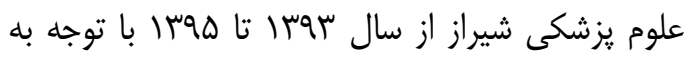

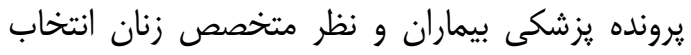

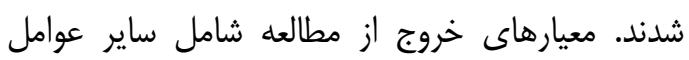

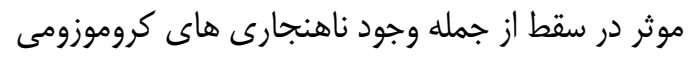

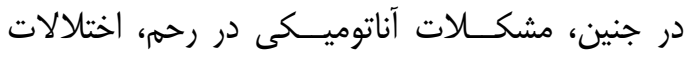

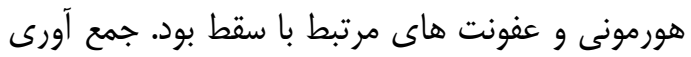

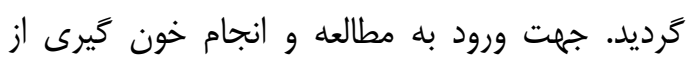
تمامى افراد مورد مطالعه رضايت نامه آكاهانها(تاييد شده توسط كميته اخلاق دانشخاه علوم يزشكى شيراز) خرفته شد.

نمونه كيرى/ز جفت: نمونه هاى جفت سالم از افراد داوطلب سزارين پِ از از اخذ رضايت نامه آكًاهانها(تاييد

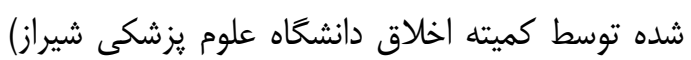

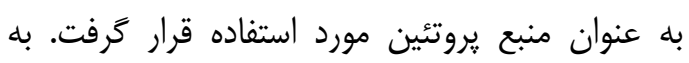

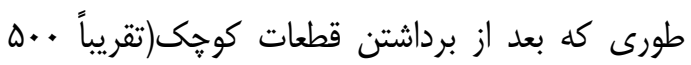

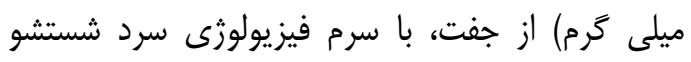

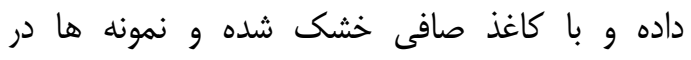

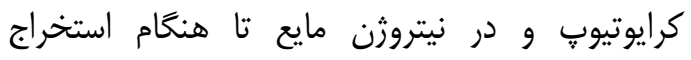
يروتئين نخمهارى شدند.

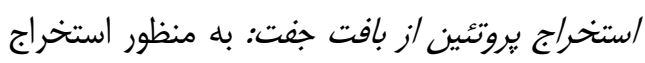

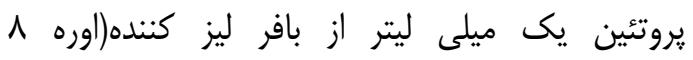

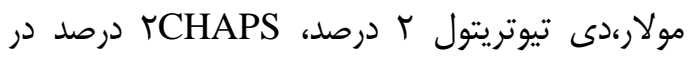

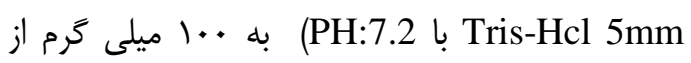

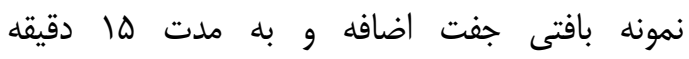
انكوباسيون بر روى يخ صورت گرَفت. در ادامه نمونه

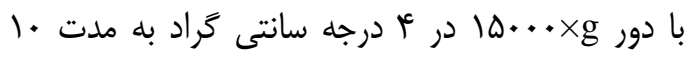

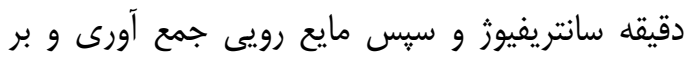

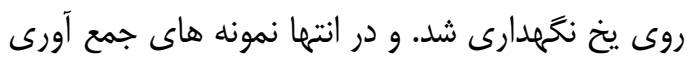

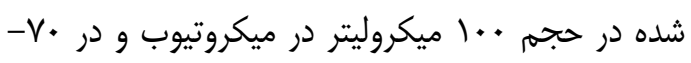

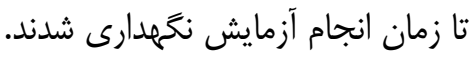

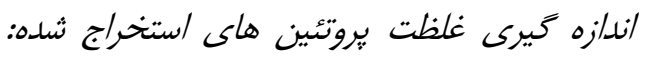
جهت اندازه گيرى غلظت يروتئين از دستخاه يِيكو دراب

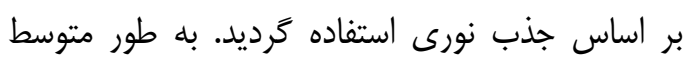




\section{كرفته شدند.

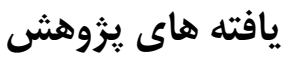

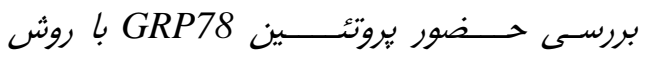

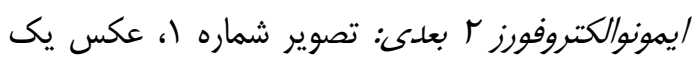

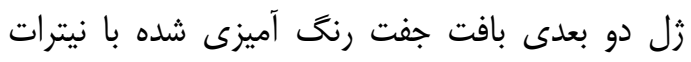

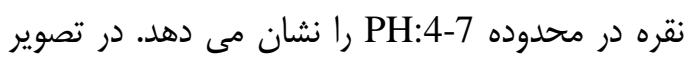

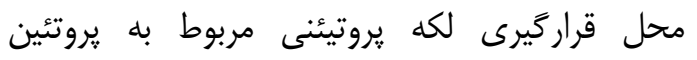

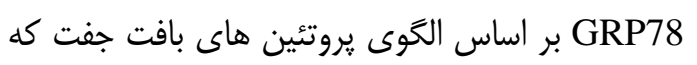

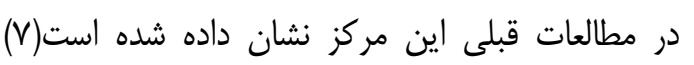

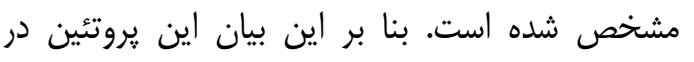
سطح سلول هاى جفت مورد تاييد قرار خرفت.
روش دستى استفاده شد ابتدا بهترين غلظت يروتئين و

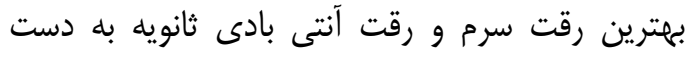

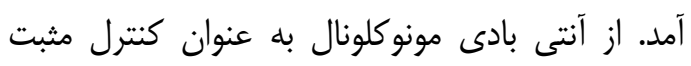

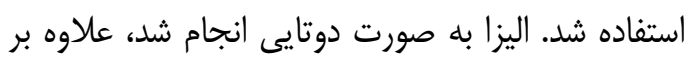
اين از دو كنترل منفى در تست استفاده كرديد. آناليز آمارى با استفاده از نرم افزار آمارى

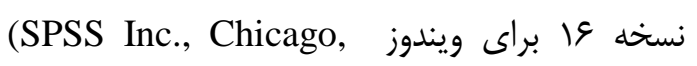
انجام شد. براى مقايسه ميانخين مقادير IL,USA)

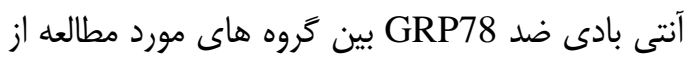
أزمون Student t-test استفاده شد. عادئ علاوه بر اين، مقادير P كمتر از هـ/• از نظر آمارى معنى دار در نـظر

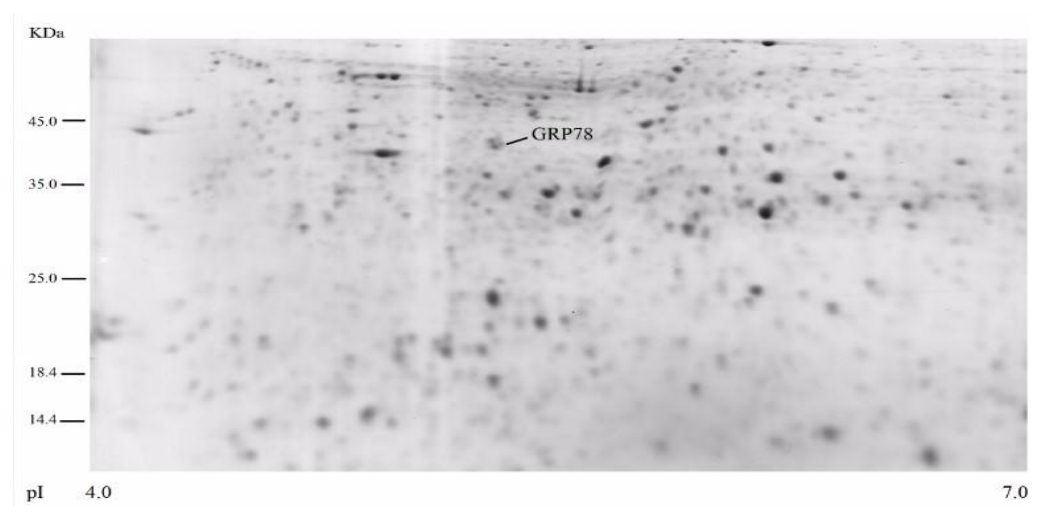

PH:4-7 تصوير شماره ا. زل رنكَ آميزى شده توسط نيترات نقره در محدوده

انجام شد. همان طور كه در تصوير شماره r نشان داده

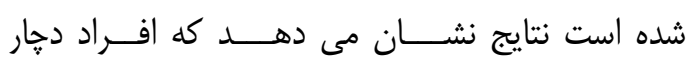

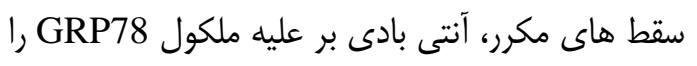
در سرم خود دارا مى باشند.

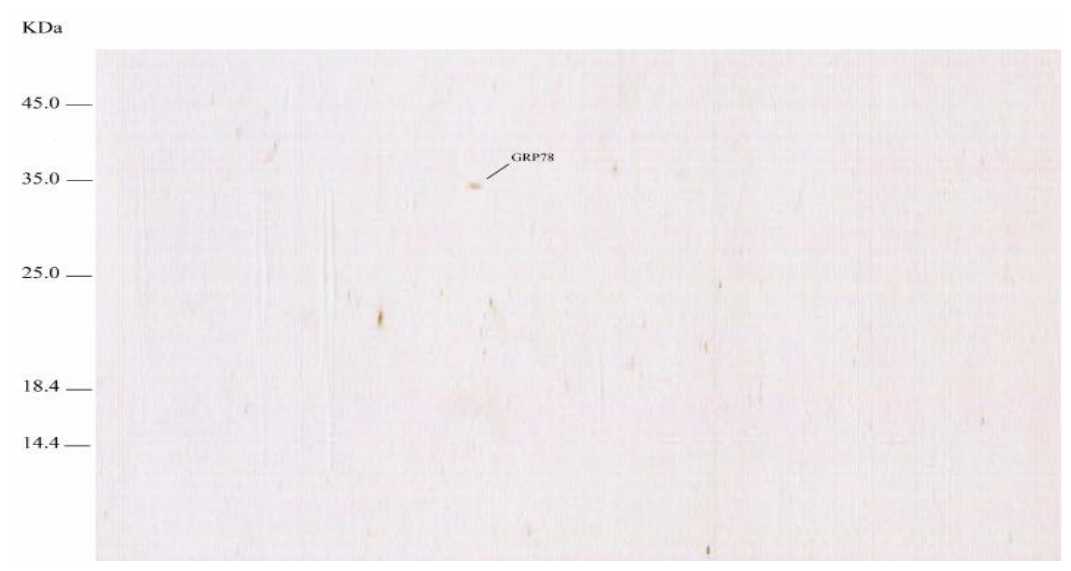

تصوير شماره r. آنتى بادى عليه GRP78 بر روى كاغذ PVDF

IVT
وسترن بلات: جهت بررسـى و تاييــد حضـــور

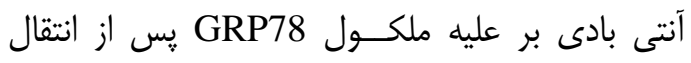

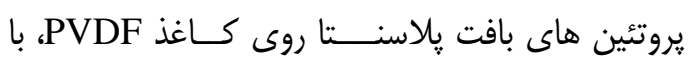

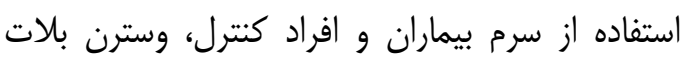


است نتايج نشان داد كه ميزان آنتى بادى عليه يروتيئن GRP78 در افراد سالم بيشتر از افراد دجار سقط مكرر است. با اين وجود اين تفاوت از نظر آمارى معنادار نبود(P=0.1).
بررسى حضور آنتى بادى عليه بروتئين GRP78 در

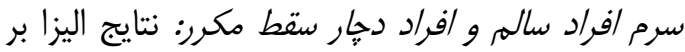
اساس ميزان جذب نورى ارائه شده است. همان طور كه در جدول شماره ا و نمودار شماره النشان داده شده الندان

\section{جدول شماره اــ مقايسه نتايج آزمايش اليزا بر روى نمونه هاى افراد بيمار و سالم با استفاده از آزمون تى تست

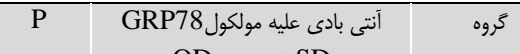 OD mean \pm SD

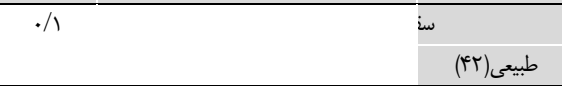

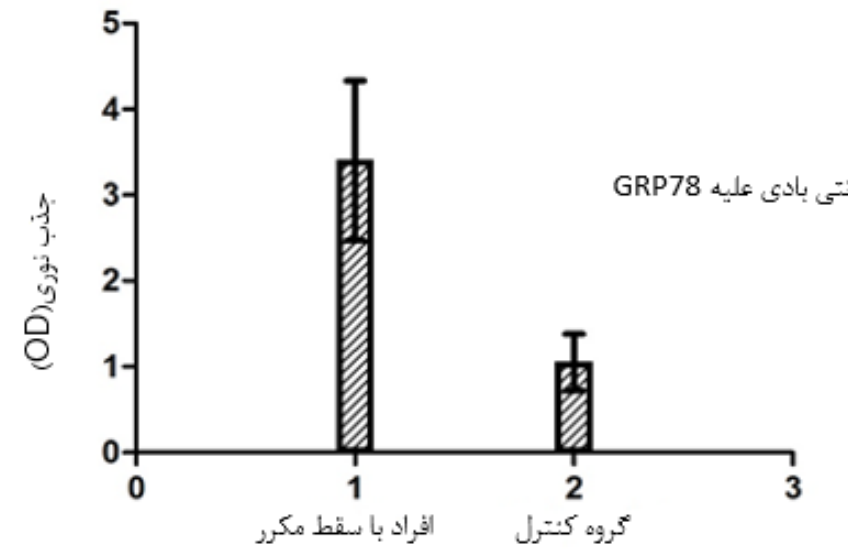

نمودار شماره ا. مقايسه ميزان آنتى بادى در افراد تَروه كنترل و كَروه بيمار با استفاده از آزمون تى تست

تروفوبلاست بيان مى شود(ع|،ه|). در اين مطالعه نيز

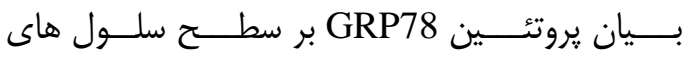

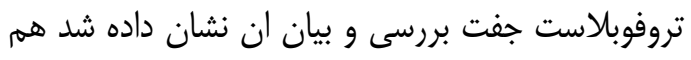

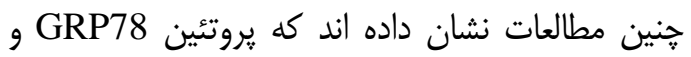
آنتى بادى عليه آن در پالاسماى زنان باردار وجود دارد.

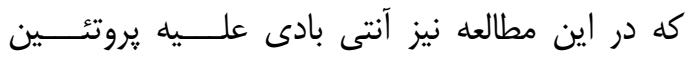

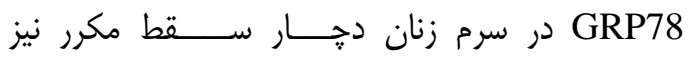

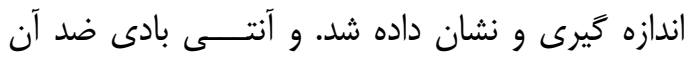
مى تواند در تهاجم سلول هاى تروفوبلاست نقش داشته باشد. GRP78 هم جنين بر روى سطوح سلولى

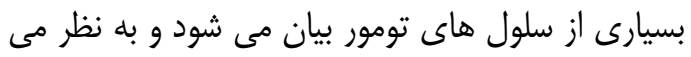

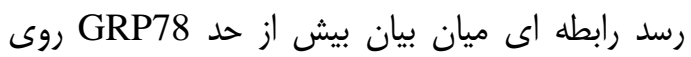
سطوح سلولى و متاستاز سلول هاى سرطانى وجود دارد(1)، سا-11). اخر جه دليلى دقيق براى بيان سطح سلى سلى
بحث و نتيجه كيرى در اين مطالعه نشان داده شد كه آنتى بادى عليه

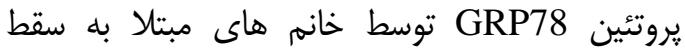

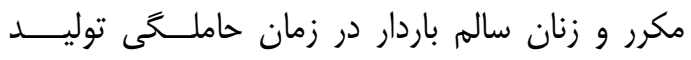
مى شود. بررسى آمارى نشان داد كه با وجود اين كه إنه ميزان اين آنتى بادى در افراد دجار سقط مكرر كمتر از از لمان خانم هاى با باردارى طبيعى است، اما اين تفاوت از نظر

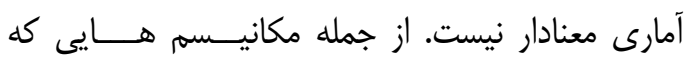

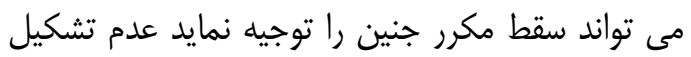
صحيح بافت קهلاسنتا مى باشد. در تاييد اين مطلب، عدم شكل كيرى صحيح بافت جفت در اختلالات

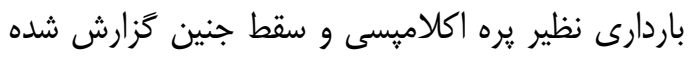

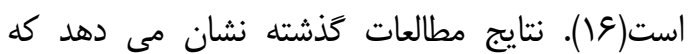
يروتئين GRP78 به ميزان بالايى بر سطح سلول هاى ملئه نئ دهان 
كرفت نشان داده شد كه در •ــ-· درصــد ســرم خانم هاى مبتلا به يره اكلاميسى آنتى بادى عليه اين دو يروتئين وجود دارد()). در مطالعه انجام شده ديخرى نيز در ابتدا ارتباط

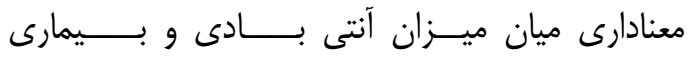
يره اكلاميسى مشاهده نشد اما وقتى بيماران بر اساس شدت بيمارى مورد بررسى قــــرار خـــــنتند ميزان

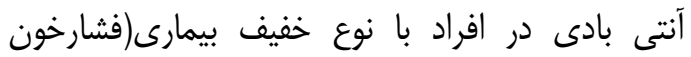

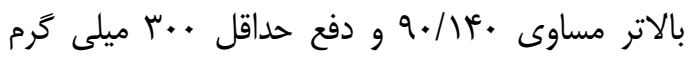
يروتئين) با افراد سالم تفاوت قابل ملاحضه اى نداشت

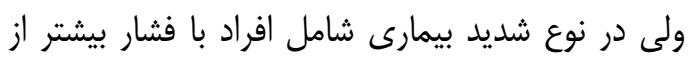

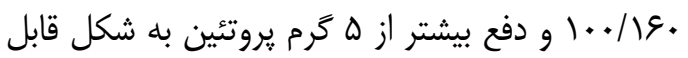

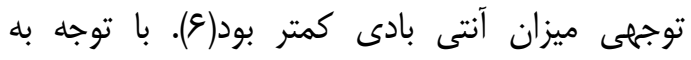

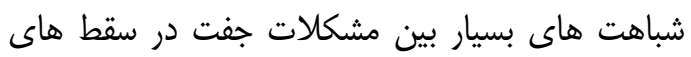

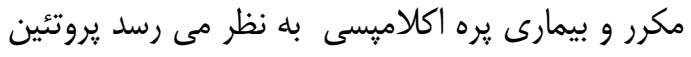

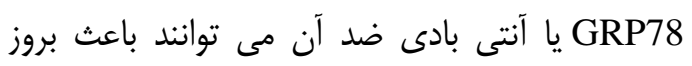

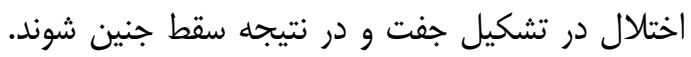

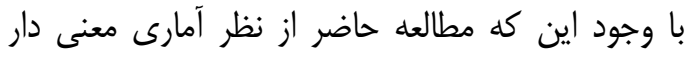

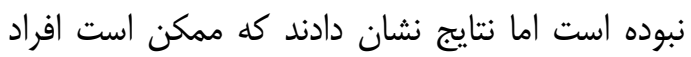
دجار سقط مكرر در توليد آنتى بادى ضد ضئ بروتئين

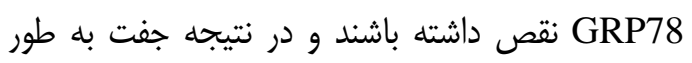
صحيح تشكيل نشود. از طرفى نتايج به دست آمده از

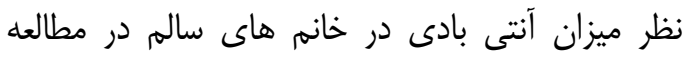

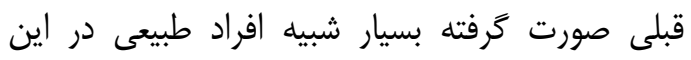
مطالعه است. با توجه به اين كه اين مطالعه تنها مطالعه

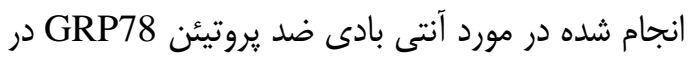

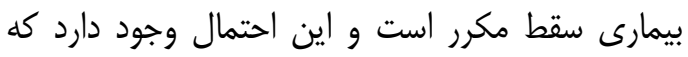

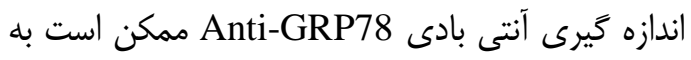
عنوان يك نشانخر جديد براى ييش بينى سقط مورد

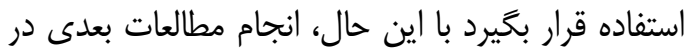

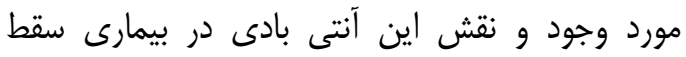
مكرر ضرورى به نظر مى رسد.

سياسگَزارى

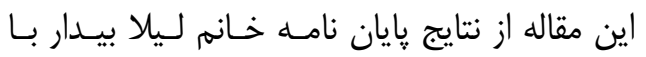
حمايت معاونت يثوهشى و حمايت مركز تحقيقات ييوند

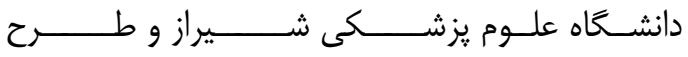

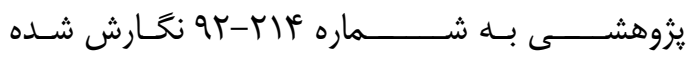

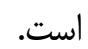

سلولى GRP78 هنوز شــناخته نشـــده است، به نظر

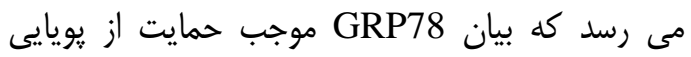

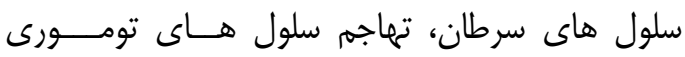

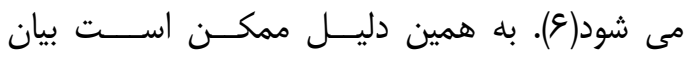
GRP78 بر سطح سلول هاى تروفوبلاست مخصوصاً

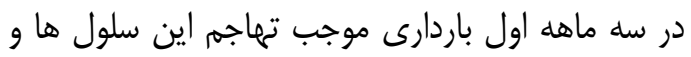
تشكيل مناسب جفت بيانجامد. برخى از مطالعات انجام

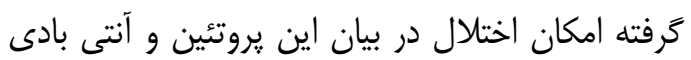

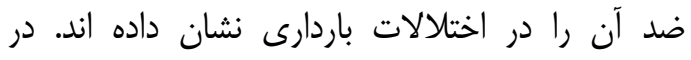
مطالعه صورت گرفته توسط Fradet و همكاران نشان

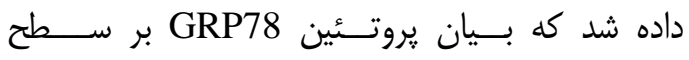

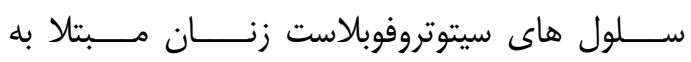

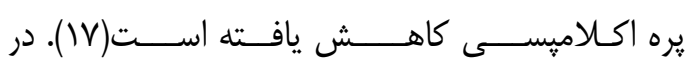

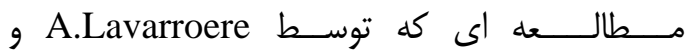

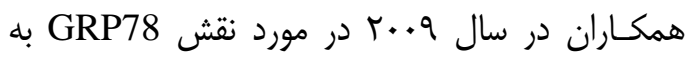

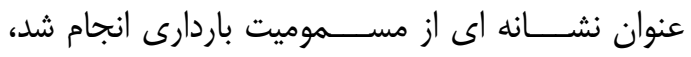

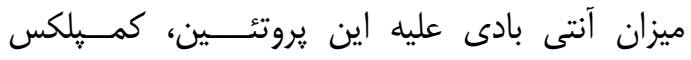

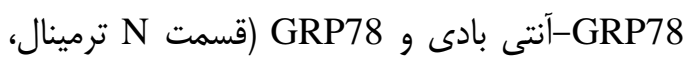

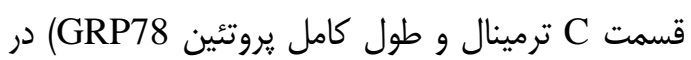

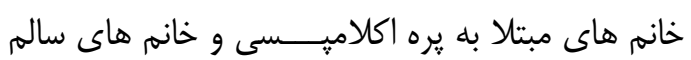

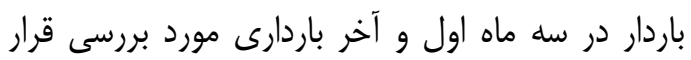
كرفت. نتايج نشان داد كه تفاوتى در ميزان آنتى بادى دارد

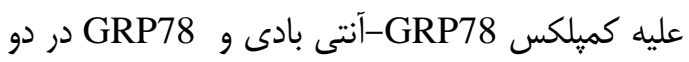
كروه مورد مطالعه وجود ندارد اما ميزان آنتى بادى عليه بادي

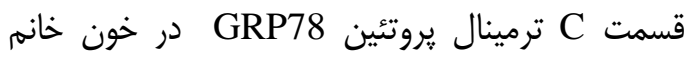

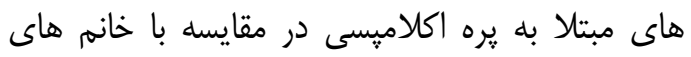

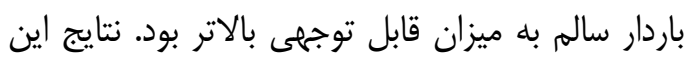

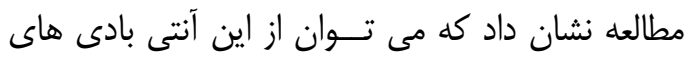

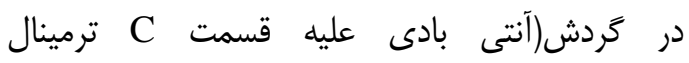
خون كه منعكس كننده خصوصيت تهاجمى (GRP78 سلول هاى سيتوتروفبلاست هستند به عنوان ماركرى

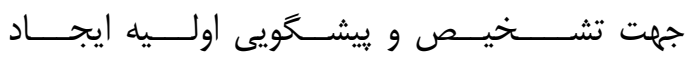

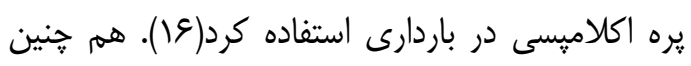
در مطالعه ديخرى كه توسط غارثى فرد و همكاران در دران

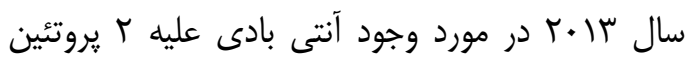

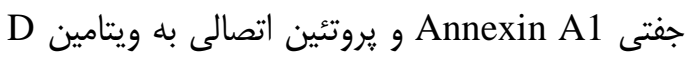
كه در سرم خانم هاى (Vit D binding protein) مبتلا به يره اكلاميسى و خانم هاى باردار سالم صورت دان 
References

1. Baek KH, Lee EJ, Kim YS. Recurrent pregnancy loss the key potential mechanisms. Trends Mol Med2007;13:310-

7. doi: 10.1016/j.molmed.2007.05.005

2. Cunningham F, Leveno K, Bloom S, Spong CY, Dashe J. Williams Obstetrics. $24^{\text {th }}$ ed.Mcgraw Hill Publication. 2014.

3. Ansari A, Kirkpatrick B. Recurrent pregnancy loss. An update. J Reprod Med1998;43(9):806-14.

4. Naseri AF, Morovati S. A survey on relationship between progesterone receptor gene polymorphisms and recurrent spontaneous abortions. 2016.

5. Pandey MK, Rani R, Agrawal S. An update in recurrent spontaneous abortion. Arch Gynecol Obstet2005;272:95-108. doi: 10.1007/s00404-004-0706-y

6. Rezanezhad L, Zolghadri J, Gharesifard B. Importance of anti-GRP78 antibody in pre eclampsia. Iran J Immunol2013;10:238. doi: IJIv10i4A5

7. Gharesifard B, Jafarzadeh L, Ghaderishabankareh F, Zolghadri J, Kamalisarvestani E. Presence of autoantibody against two placental proteins, peroxiredoxin 3 and peroxiredoxin 4 , in sera of recurrent pregnancy loss patients. Am J Rep Immunol2013;69:248-55. doi: 10.1111/aji.12042

8. Behrouz GF, Farzaneh GS, Leila J, Jaleh Z, Eskandar KS. Presence of auto antibody against two placental proteins, annexin A1 and vitamin $\mathrm{D}$ binding protein in sera of women with pre eclampsia. J Rep Immunol2013;99:10-6. doi: 10.1016/j.jri.2013.04.007

9. Dudek J, Benedix J, Cappel S, Greiner M, Jalal C, Muller L, et al. Functions and pathologies of $\mathrm{BiP}$ and its interaction partners. Cell Mol Life Sci2009;66:155669. doi: 10.1007/s00018-009-8745-y

10. Stagnarogreen A. Thyroid antibodies and miscarriage where are we at a generation later? J Thyroid Res2011;2011. doi: 10.4061/2011/841949
11. Delie F, Petignat P, Cohen M. GRP78 protein expression in ovarian cancer patients and perspectives for a drugtargeting approach. J Oncol2012;2012. doi: 10.1155/2012/468615

12. Fu Y, Lee AS. Glucose regulated proteins in cancer progression, drug resistance and immunotherapy. Cancer Biol Ther2006;5:741-4.

doi: abs/10.4161/cbt.5.7.2970

13. Li J, Lee AS. Stress induction of GRP78/BiP and its role in cancer. Curr Mol Med2006;6:45-54. doi: $10.2174 / 156652406775574523$

14. Quinones QJ, de Ridder GG, Pizzo SV. GRP78: a chaperone with diverse roles beyond the endoplasmic reticulum. Histol Histopathol2008;23:1409-16. doi: 10.14670/HH-23.1409

15. Gonzalezgronow M, Cuchacovich M, Llanos C, Urzua C, Gawdi G, Pizzo SV. Prostate cancer cell proliferation in vitro is modulated by antibodies against glucose regulated protein 78 isolated from patient serum. Cancer Res2006;66:11424-31. doi: 10.1158/0008-5472.CAN-06-1721

16. Laverriere A, Landau $\mathrm{R}$, Charvet I, Irion $\mathrm{O}$, Bischof $\mathrm{P}$, Morales $\mathrm{M}$, et al. GRP78 as a marker of pre-eclampsia: an exploratory study. Mol Hum Reprod2009;15:569-74. doi: 10.1093/molehr/gap037

17. Fradet S, Pierredon S, Ribaux P, Epiney $\mathrm{M}$, Ya KS, Irion O, et al. Involvement of membrane GRP78 in trophoblastic cell fusion. PLoS One. 2012;7:40596. doi: 10.1371/journal.pone.0040596

18. Shin BK, Wang H, Yim AM, Le Naour F, Brichory F, Jang JH, et al. Global profiling of the cell surface proteome of cancer cells uncovers an abundance of proteins with chaperone function. J Biol Chem2003;278:7607-16. doi: 10.1074/jbc.M210455200 


\title{
Presence of anti-glucose regulated protein 78 autoantibodies in the sera of women with recurrent pregnancy loss
}

\author{
Gharesi-Fard $B^{l}$, Karimi $\mathrm{MH}^{2}$, Bidar $L^{3}$, Ali-Hasanzadeh $M^{4}$
}

(Received:

\begin{abstract}
Introduction: Recurrent pregnancy loss (RPL) is defined as three or more miscarriages prior to the $20^{\text {th }}$ week of gestation. This condition occurs in $15-20 \%$ of all pregnancies. Glucose-regulated protein 78 (GRP78) is an endoplasmic reticulum (ER) protein that is expressed on the trophoblast cells. The purpose of this study was to evaluate the presence of antiGRP78 antibodies in the sera of women with RPL.

Materials \& Methods: This case-control study was conducted 80 women referring to the Infertility Center of Shiraz University of Medical Sciences, Shiraz, Iran, during 2014-2016. The study population was assigned into two groups of case entailing 38 women with unexplained RPL and control including 42 healthy pregnant women with no history of miscarriage and a minimum of two successful pregnancies. The measurement of the anti-GRP78 antibody in the sera of the two groups was
\end{abstract}

Accepted: )

performed using the enzyme-linked immunosorbent assay (ELISA). Furthermore, western blot technique was used to assess the expression of GRP78 in placenta tissue for both groups.

Findings: The results of the western blot demonstrated the expression of GRP78 on the trophoblast cells in both groups. Furthermore, anti-GRP78 antibodies were detected in both case and control groups through ELISA. The case group had a lower level of anti-GRP78 antibodies; however, this difference was not statistically significant $(\mathrm{P}=0.1)$.

Discussion \& Conclusions: The findings of the current study revealed no significant relationship between anti-GRP78 antibody level in RPL patients and healthy pregnant subjects.

Keywords: Pregnancy, RPL, Placenta, GRP78 